\title{
Measuring the antioxidative activities of Queso Fresco after post-packaging high-pressure processing
}

\author{
Moushumi Paul ${ }^{1}$, Jeffrey D. Brewster ${ }^{2}$, Diane L. Van Hekken ${ }^{1}$, Peggy M. Tomasula ${ }^{1}$ \\ ${ }^{1}$ Dairy and Functional Foods Research Unit, USDA-ARS-NAA-ERRC, Wyndmoor, USA \\ ${ }^{2}$ Molecular Characterization of Foodborne Pathogens Research Unit, USDA-ARS-NAA-ERRC, Wyndmoor, USA \\ Email: moushumi.paul@ars.usda.gov
}

Received 2 May 2012; revised 7 June 2012; accepted 9 July 2012

\begin{abstract}
Some milk-associated proteins are known to be nutritionally valuable and form bioactive peptides that exhibit activity against hypertension and oxidative stress. Consumption of cheeses, such as the popular Hispanicstyle cheese Queso Fresco (QF), may be a vehicle for delivery of these milk-associated peptides. This paper describes the effects of high-pressure processing (HPP) on the antioxidative activity (ORAC-FL value) of water-soluble proteins extracted from QF samples. QFs were manufactured according to a commercial-make procedure using pasteurized, homogenized milk, without added starter cultures. The cheese was cut into 45 $\times 45 \times 150 \mathrm{~mm}^{3}$ blocks, double packaged in vacuum bags, and received the following HPP treatments: 200 , 400, or $600 \mathrm{MPa}$ for either $0,5,10$, or $20 \mathrm{~min}$, with warming to an internal temperature of either $22^{\circ} \mathrm{C}$ or $40^{\circ} \mathrm{C}$ prior to HPP treatment. Results show that the core temperature of the cheese during HPP directly affects the ORAC-FL value. The activities of the lower temperature cheeses are independent of time and pressure, and have a median ORAC-FL value of 27 trolox equivalents (TE). The higher temperature cheeses have higher ORAC-FL values ranging from 21.5 to 96.0 TE; the highest activity corresponded to the cheese held at $400 \mathrm{MPa}$ for the longest time under pressure (20 min). The $600 \mathrm{MPa}$ cheeses increase in activity with increasing time under pressure, but are less active than the control cheese. These results indicate that processing temperature and pressure are important factors in the antioxidative activity of these QF samples and further understanding of the roles of these variables may lead to the manufacture of healthier and more nutritious cheeses and dairy products.
\end{abstract}

Keywords: ORAC-FL Assay; Queso Fresco; Antioxidant; High Pressure Processing

\section{INTRODUCTION}

American consumers are increasingly interested in im- proving the quality of their diet. To this end, they are searching for food products with higher nutritional benefits and health value. In an effort to address this, a number of functional foods are being studied that have enhanced or enriched health benefits [1]. Foods that potentially prevent illness or reduce the risk of disease are especially promising as products addressing this need. Included among these are products with high levels of antioxidants that may reduce the risk of cancer and prevent cardiovascular disease [2].

Reactive oxygen species (ROS) and other free radicals can be produced in the body and can oxidatively damage DNA, proteins and other important cellular components [3]. They have been implicated in the occurrence of diabetes, neurodegenerative diseases and cancer, and are generally associated with aging [4]. Antioxidants are involved in the management of oxidative stress that leads to the formation of ROS and free radicals. Due to their protective role against various types of diseases, how and where antioxidants are produced and their mechanism of action have been focuses of research as potential methods of prevention and treatment.

Antioxidants are found naturally in many types of fruits and vegetables, e.g. berries [5], nuts [6,7], and leafy greens [8]. They can also be obtained from a number of animal sources, including egg [4], porcine myofibrillar proteins [9], fish proteins [10], and milk-associated proteins [11]. In recent years, a number of researchers have been mining fragments of milk proteins for potential antioxidants for commercial use. Previous studies have found peptides, obtained via enzymatic hydrolysis of $\alpha$-lactalbumin ( $\alpha$-LA) and $\beta$-lactoglobulin ( $\beta$-LG), that have antioxidative activity greater than that of butylated hydroxyanisole (BHA), a synthetic antioxidant currently used in the food industry [12]. Other studies compared antioxidative activities of whey protein proteolytic fragments derived from bovine and camel milk in an effort to find active peptides for use in food processing and potential inclusion in functional foods [13]. Indian scientists have assessed the antioxidative activity of buffalo 
and cow milk and curd to evaluate the nutritive value of these commonly consumed Indian foods [14]. Most recently, scientists have shown whey protein concentrate to have dose-dependent antioxidant, radical scavenging and metal-chelating effects in rats and may provide protection against known oxidative agents [2].

Queso fresco (QF) is a fresh soft cheese that is highly popular among the growing Hispanic population in the US It is generally made without the use of starter cultures, and as a high moisture cheese with $\mathrm{pH}>6$, provides a fertile breeding ground for any number of spoilage and pathogenic bacteria. In this study, QFs are subjected to high-pressure processing (HPP) after packaging as a method to inhibit food spoilage and bacterial growth. While other bioactivities of QFs, like antihypertensive activity, have been previously examined $[15,16]$, few studies have assessed antioxidative activities of QFs or examined the effect of HPP and temperature on these bioactive compounds. Both of these issues are addressed in this paper.

\section{MATERIALS AND METHODS}

Fluorescein (FL), sodium salt, 6-Hydroxy-2,5,7,8-tetramethylchroman-2-carboxylic acid (Trolox), and 2,2'azobis (2-methylpropionamidine) dihydrochloride (AAPH) were purchased from Sigma-Aldrich (St. Louis, MO). A $1 \mathrm{mM}$ fluoroscein stock solution was made in $75 \mathrm{mM}$

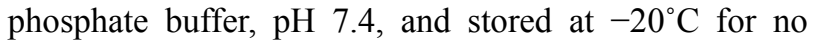
longer than 4 weeks. AAPH and Trolox solutions in 75 $\mathrm{mM}$ phosphate buffer, $\mathrm{pH} 7.4$, were made fresh daily.

\subsection{Cheesemaking}

QFs were manufactured according to a modification of a procedure used by Guo et al. [17]. Cheesemilk was standardized to $3.5 \%$ fat, pasteurized at $72^{\circ} \mathrm{C} / 15 \mathrm{~s}$, and homogenized at 6.9/3.4 MPa. To this was added $0.1 \% \mathrm{CaCl}_{2}$ and no starter cultures were added-Milk (181 L) was warmed to $32^{\circ} \mathrm{C}$ and coagulated with chymosin $(130 \mathrm{~mL} /$ 1000L milk; CHY-MAX, Chr. Hansen, Inc., Milwaukee, WI). The gel was cut after $30 \mathrm{~min}$ and the temperature was raised to $39^{\circ} \mathrm{C}$. The curd was cooked for $30 \mathrm{~min}$ and half of the whey was drained. To this was added salt (14.5 g salt $/ \mathrm{kg}$ milk) in 3 applications over $15 \mathrm{~min}$. The remaining whey was drained, curds were removed to covered trays and chilled at $4^{\circ} \mathrm{C}$ until the core temperature $<21^{\circ} \mathrm{C}$. The curds were milled (Bosch universal 6610UC/01 FD, Robert Bosch Hausgerate Gmbh, Dillingen, Germany), hand packed into molds, and stored overnight at $4^{\circ} \mathrm{C}$. On the following day, one large block of cheese was divided into smaller blocks $(45 \times 45 \times 150$ $\mathrm{mm}^{3}$ ) and each smaller block was double vacuum bagged. Samples were stored at $4^{\circ} \mathrm{C}$ overnight. Two batches of cheese were manufactured over an 8 wk period.

\subsection{High Pressure Processing (HPP)}

Prior to HPP treatment, samples were warmed to a core temperature of either $22^{\circ} \mathrm{C}$ (L cheeses) or $40^{\circ} \mathrm{C}(\mathrm{H}$ cheeses). One sample was placed in the chamber of a 2-L High Pressure Food Processor (Avure Inc., Columbus, $\mathrm{OH}$ ) and processed at either 200,400 , or $600 \mathrm{MPa}$ for either 5,10 , or $20 \mathrm{~min} ; 3$ blocks/treatment/batch. Samples were stored at $4^{\circ} \mathrm{C}$ for $7-8 \mathrm{~d}$ until assayed. Control samples without HPP were prepared at each core temperature.

\subsection{Protein Extraction}

Water-soluble proteins were extracted in the following manner [18]: $5 \mathrm{~mL}$ of extraction buffer (0.166 M Tris, 1 $\mathrm{mM}$ ethylenediaminetetraacetic acid (EDTA), $\mathrm{pH}$ 8.0) was added to $2 \mathrm{~g}$ of cheese. This mixture was homogenized by sonication for $6 \mathrm{~min}$. To this mixture, $5 \mathrm{~mL}$ of $7 \%$ sodium dodecyl sulfate (SDS) was added and further sonicated for $3 \mathrm{~min}$. While on ice, $2 \mathrm{~mL}$ of $10 \mathrm{~mm}$ dithiothreitol (DTT) was added and the solution was stirred at $0^{\circ} \mathrm{C}$ for $15 \mathrm{~min}$. The resulting solution was centrifuged at $30,000 \mathrm{~g}$ for $1 \mathrm{hr}$ at $4^{\circ} \mathrm{C}$. The supernatant was filtered and lyophilized. The water-soluble protein extracts were stored at $-20^{\circ} \mathrm{C}$.

\subsection{ORAC-FL Assay}

The oxygen radical absorbance capacity-fluorescein (ORAC-FL) assay procedures of Ou et al. [19] and Dávalos et al. [20] were adapted as follows: Reactions were carried out in $75 \mathrm{mM}$ phosphate buffer, $\mathrm{pH} 7.4$ and the final volume of each reaction was $200 \mu \mathrm{L}$. Protein extract samples were used at concentrations ranging from $0.01-0.1 \mathrm{mg} / \mathrm{mL}$ as determined by Pierce bicinchoninic acid (BCA) protein assay (Thermo Scientific). Fluorescein solutions were used at a concentration of $200 \mathrm{nM}$. A 96-well microplate was used for all assays. Protein extract sample $(10-80 \mu \mathrm{L})$, fluorescein $(50 \mu \mathrm{L})$ solution, and extra buffer to bring the total volume to $130 \mu \mathrm{L}$, were placed in wells $1-8$ of a microplate row. The mixture was preincubated at $37^{\circ} \mathrm{C}$ for $15 \mathrm{~min}$. AAPH $(50 \mu \mathrm{L}$, $20 \mathrm{mM}$ final concentration) was added quickly to wells via multichannel pipet and the microplate was immediately placed in the fluorescence plate reader. The fluorescence (483 nm excitation, $525 \mathrm{~nm}$ emission) was recorded every minute for 80 minutes, with shaking prior to each reading. A blank (FL + AAPH) using phosphate buffer instead of protein extract sample and eight calibration samples using Trolox $(1-8 \mu \mathrm{M})$ as standard antioxidant were included with each assay. Each assay contained reaction mixtures prepared in triplicate.

Data was collected using a Tecan Safire II (Durham, NC) fluorescence plate reader. Data was compiled in an 
Excel (Microsoft, Roselle, IL) spread sheet and calculations were carried out. Sample curves (fluorescence versus time) were normalized to the blank curve by multiplying original data by fluorescence ${ }_{\text {blank }, \mathrm{t}=0} /$ fluorescence sample, $\mathrm{t}=0$. From these curves, the area under the curve (AUC) was calculated as:

$$
\mathrm{AUC}=1+\sum_{i=0}^{i=80} f_{i} / f_{0}
$$

where $f_{0}$ is the initial fluorescence reading at time $=0$, and $f_{i}$ is the fluorescence at time $=i$.

The net AUC was calculated by subtracting the AUC corresponding to the blank sample. Net AUC versus protein extract sample concentration data were plotted and fit with a linear curve to provide the ORAC-FL values. These values are expressed as Trolox equivalents (TE) using the standard curves for Trolox from each assay. The final TE values are in $\mu \mathrm{M}$ trolox equivalent/g cheese sample.

\subsection{Statistical Analysis}

The ORAC-FL values were analyzed as a randomized complete block design with 3 factors (temperature, pressure, and time) using the Mixed procedure of the SAS System for Windows, version 9.22 [21]. The Bonferroni $t$-test was used to determine significant differences among means, and differences were described as significant only if $P<0.05$.

\section{RESULTS AND DISCUSSION}

The assay used to evaluate the water soluble protein extracts from QF samples in this study was introduced and validated as a means to probe the antioxidative activity of many different sample types by Ou et al. [19] This report provided values for blueberry (23748 TE/L), grape (31441 TE/L), and raspberry juices (54034 TE/L), and black tea (17267 TE/L), among other samples, and has been used subsequently to assess the bioactivity of a variety of food products [22-25]. This study improved the existing methodology for measuring oxygen radical absorbance capability by introducing a protocol using fluorescein as an alternative, and less inexpensive, fluorescent probe, than those that were previously employed.

The results from the ORAC-FL assays of the QF samples in the present study (summarized in Tables 1 and 2) provided fluorescence decay curves for both the trolox standard (Figure 1) and the protein extract mixtures from the QF samples (an example of the $40^{\circ} \mathrm{C}, 610 \mathrm{MPa}$ samples is shown in Figure 2). From these curves, the ORAC-FL values were calculated. The results for the $22^{\circ} \mathrm{C}$ samples are shown in Figure 3. The overall values fell mostly within the range of 10 - 70 Trolox equivalents/g cheese $(\mathrm{TE} / \mathrm{g})$, with a median value of $20.7 \mathrm{TE} / \mathrm{g}$.
Table 1. Pressures and holding times employed for the low temperature $\left(22^{\circ} \mathrm{C}\right)$ samples.

\begin{tabular}{ccc}
\hline $\begin{array}{c}\text { L Samples } \\
\text { (Core Temp 22 }\end{array}$ & $\begin{array}{c}\text { Pressure Applied } \\
\text { (MPa) }\end{array}$ & $\begin{array}{c}\text { Time Held at HP } \\
\text { (min) }\end{array}$ \\
\hline L control & None & None \\
L 205 & 200 & 5 \\
L 210 & 200 & 10 \\
L 220 & 200 & 20 \\
L 405 & 400 & 5 \\
L 410 & 400 & 10 \\
L 420 & 400 & 20 \\
L 605 & 600 & 5 \\
L 610 & 600 & 10 \\
L 620 & 600 & 20 \\
\hline
\end{tabular}

Table 2. Pressures and holding times employed for the high temperature $\left(40^{\circ} \mathrm{C}\right)$ samples.

\begin{tabular}{ccc}
\hline $\begin{array}{c}\text { H Samples } \\
\text { (Core Temp 40 }{ }^{\circ} \text { C) }\end{array}$ & $\begin{array}{c}\text { Pressure Applied } \\
\text { (MPa) }\end{array}$ & $\begin{array}{c}\text { Time Held at HP } \\
\text { (min) }\end{array}$ \\
\hline H control & None & None \\
H 205 & 200 & 5 \\
H 210 & 200 & 10 \\
H 220 & 200 & 20 \\
H 405 & 400 & 5 \\
H 410 & 400 & 10 \\
H 420 & 400 & 20 \\
H 605 & 600 & 5 \\
H 610 & 600 & 10 \\
H 620 & 600 & 20 \\
\hline
\end{tabular}

The lowest antioxidative activity was $10.2 \mathrm{TE} / \mathrm{g}$ (well below the median value), measured for the cheese processed at the highest pressure (600 MPa) for the longest time $(20 \mathrm{~min})$. The highest ORAC-FL value $(67.6 \mathrm{TE} / \mathrm{g})$ corresponds to the QF sample processed for $10 \mathrm{~min}$ at a pressure of $400 \mathrm{MPa}$. The $22^{\circ} \mathrm{C}$ control cheese has a measured antioxidative activity value of $14.1 \mathrm{TE} / \mathrm{g}$ cheese that is significantly lower than that of the sample held at $400 \mathrm{MPa}$ for $10 \mathrm{~min}(P<0.05)$ and slightly higher than that of the sample held at $600 \mathrm{MPa}$ for 20 $\min (P<0.05)$, indicating that length of processing time and pressure used do impact the ORAC-FL value of these samples. The samples held at 200 and $400 \mathrm{MPa}$ for 


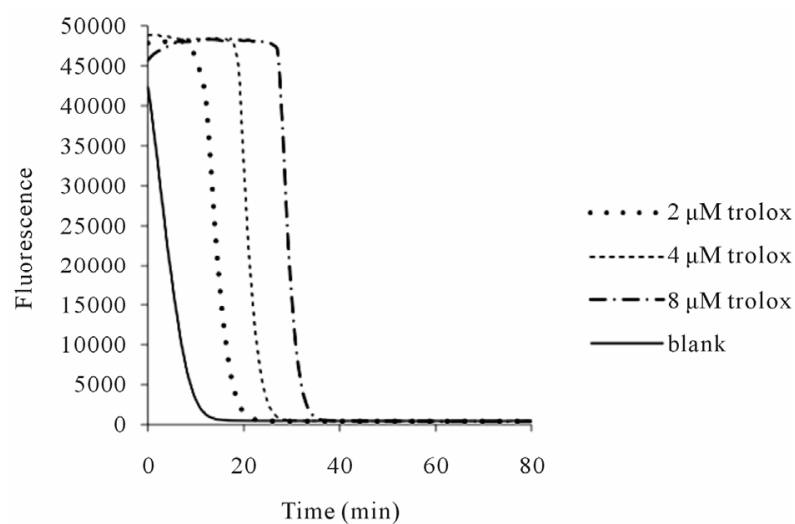

Figure 1. Fluorescence decay curves of fluorescein alone (blank) and with trolox standard at various concentrations.

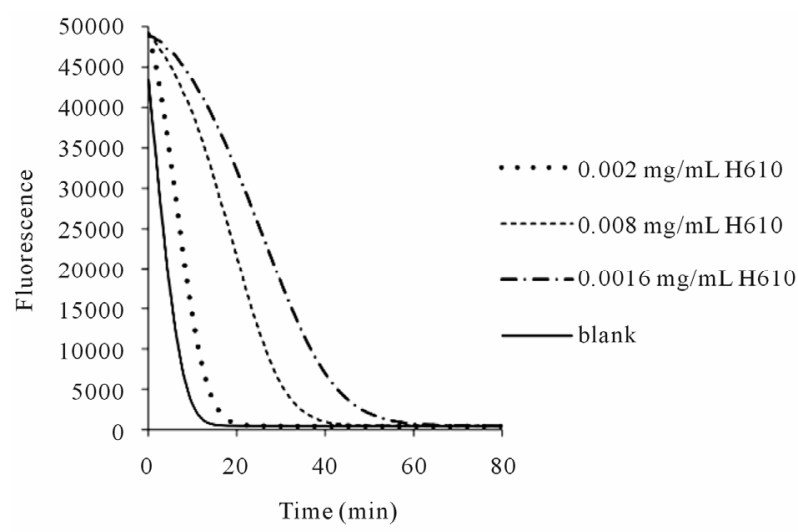

Figure 2. Fluorescence decay curves of fluorescein alone (blank) and with sample at $40^{\circ} \mathrm{C}$ held at $600 \mathrm{MPa}$ for $10 \mathrm{~min}$ (labeled as $\mathrm{H} 610)$ at various concentrations.

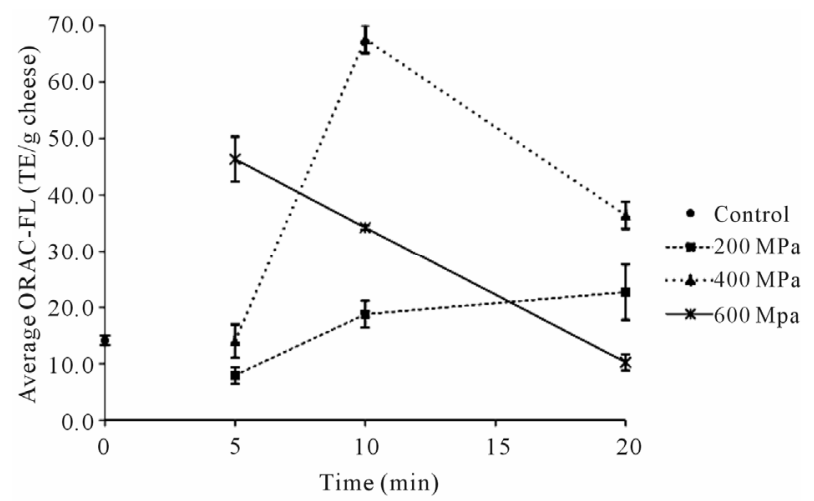

Figure 3. Average antioxidative values measured for low temperature (core temp of $22^{\circ} \mathrm{C}$ ) cheeses at 0 (control), 200, 400 and $600 \mathrm{MPa}$ held for 5, 10, and $20 \mathrm{~min}$.

5 min have similar $(P>0.05)$ ORAC-FL values $(8.0$ and 14.0 TE/g, respectively), while the sample held at 600 MPa for $5 \mathrm{~min}$ is significantly $(P<0.05)$ higher in activity $(46.4 \mathrm{TE} / \mathrm{g})$, indicating higher pressure $(600 \mathrm{MPa}$ vs. 200 or 400) for the same duration of time $(5 \mathrm{~min})$ led to greater than three-fold higher activity. The influence of pressure on the cheeses processed for 10 and 20 minutes is less clear with the activity of the cheese held at 400 MPa increasing significantly $(P<0.05)$ from 5 to $10 \mathrm{~min}$ to the highest measured ORAC-FL value and then decreasing significantly $(P<0.05)$ when the length of time is increased to $20 \mathrm{~min}$ at the same processing pressure. Similarly, the overall activity significantly decreases $(P<$ 0.05 ) incrementally at longer processing times ( 5 to 10 to $20 \mathrm{~min}$ ) when the pressure is increased to $600 \mathrm{MPa}$, most evidently in the 20 min sample having the lowest measured ORAC-FL value for these samples.

The ORAC-FL values measured for the higher temperature samples at core temperature of $40^{\circ} \mathrm{C}$ have a more distinguishable pattern (Figure 4). The ORAC-FL value of the $40^{\circ} \mathrm{C}$ control sample $(51.1 \mathrm{TE} / \mathrm{g})$ is significantly higher $(P<0.05)$ than that of the $22^{\circ} \mathrm{C}$ control sample (more than 3-fold), indicating that higher core temperature leads to increased antioxidative activity. Accordingly, the median ORAC-FL value measured for the $40^{\circ} \mathrm{C}$ cheeses is $49.1 \mathrm{TE} / \mathrm{g}$, which is considerably higher than that of the $22^{\circ} \mathrm{C}$ cheeses, with the lowest activity $(14.0 \mathrm{TE} / \mathrm{g})$ corresponding to the cheese held at $400 \mathrm{MPa}$ for $5 \mathrm{~min}$ and the highest activity $(89.8 \mathrm{TE} / \mathrm{g})$ measured for the cheese held at $400 \mathrm{MPa}$ for $20 \mathrm{~min}$. The results for the $40^{\circ} \mathrm{C}$ cheeses also show that at pressure of $400 \mathrm{MPa}$, increased time from 5 to 10 to 20 min leads to higher ORAC-FL values, indicating that length of processing time influences activity as well. The $200 \mathrm{MPa}$ cheeses display a trend of activity decreasing from 5 to $10 \mathrm{~min}$ of HPP and then increasing at $20 \mathrm{~min}$, while the $600 \mathrm{MPa}$ cheeses decrease from 5 to $10 \mathrm{~min}$ of HPP and then remain the same after $20 \mathrm{~min}$ (slightly decreased with $P>0.05$ ) of processing.

The antioxidative activities of proteins from bovine milk have been examined in previous work using various assays [26-28]. These studies have shown that small molecule radical scavengers such as ascorbate and urate along with other components like caseins and whey pro-

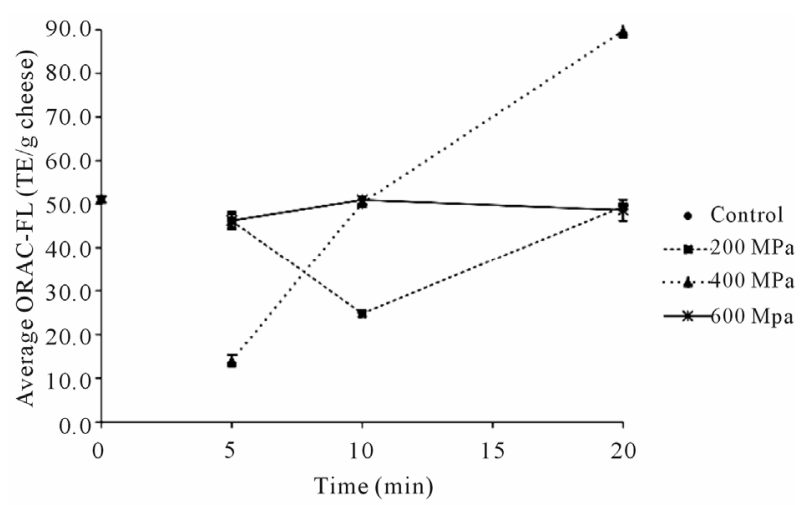

Figure 4. Average antioxidative values measured for high temperature (core temp of $40^{\circ} \mathrm{C}$ ) cheeses at 0 (control), 200, 400 and $600 \mathrm{MPa}$ held for 5, 10, and $20 \mathrm{~min}$. 
teins are contributors to the overall antioxidative activity of milk. While this type of activity has been investigated in milk, these assays have not been extended to assess the antioxidants in other dairy products like cheese.

Previous studies have been conducted on the effects of high pressure on proteins in bovine milk and whey. Casein micelles are disrupted by high-pressure treatments, which may lead to more individual casein molecules in milk serum [29,30]. Additionally, high-pressure treatment $(>400 \mathrm{MPa})$ leads to denaturation of the two major whey protein components, $\alpha$-LA and $\beta$-LG, as evidenced by a loss of solubility, and is more pronounced with increasing treatment time and temperature. This effect has been studied in liquid milk and these denatured proteins are known to associate in greater concentrations with insoluble casein micelles; however the manner in which the insolubility of denatured $\alpha$-LA and $\beta$-LG manifests itself in cheese that is processed post-manufacture is unknown [31].

Plasmin (PL), and cathepsin D are natural proteases that exist in bovine milk that are affected by HPP as well. These enzymes contribute to the breakdown of milk proteins that eventually leads to the production of bioactive peptides [32,33]. Previous work has shown that at elevated pressures $(200-650 \mathrm{MPa})$ and temperatures, the activity of PL decreases in direct correlation with temperature and duration under pressure [34]. This study also found cathepsin D to be relatively resistant to highpressure treatment at room temperature, but showed a marked decrease in activity at higher temperatures. The effect of pressure on the denaturation of $\beta$-LG and its susceptibility to proteolysis has also been addressed [35]. It was shown that increased pressure $(200-400 \mathrm{MPa})$ led to higher extents of protein unfolding, which was subsequently more susceptible to proteolysis by the enzymes pepsin and chymotrypsin.

Prior research suggests that some antioxidative activity associated with dairy products can be attributed to bioactive peptides derived from milk proteins via proteolysis [11]. The QFs examined in this study were subjected to HPP post-packaging, meaning that there may have been proteases (from the milk itself or any contaminating bacteria, etc.) initially present in the cheesemilk that remained active throughout cheesemaking prior to HPP. Many of the differences observed between the lower and higher temperature cheeses may be attributable to proteolytic activity and the extent of overall protein degradation at the HPP temperatures. The $22^{\circ} \mathrm{C}$ control sample has a measured ORAC-FL value one-third of that corresponding to the $40^{\circ} \mathrm{C}$ control cheese. The proteins in the higher temperature cheese were likely more accessible to proteases due to the elevated temperature facilitating more extensive proteolysis. This reasoning can be applied to trends in the differences amongst the
$200 \mathrm{MPa}$ samples at higher and lower temperatures, e.g. the $22^{\circ} \mathrm{C}$ sample held at $200 \mathrm{MPa}$ for $5 \mathrm{~min}$ has a significantly lower $(P<0.05)$ ORAC-FL value than the corresponding $40^{\circ} \mathrm{C}$ sample held at $200 \mathrm{MPa}$ for $5 \mathrm{~min}$, and so on.

The effects of HPP on the antioxidative activity are not as clear. For 200 and $400 \mathrm{MPa}, 5$-minute exposure significantly decreased (200 MPa sample, $P<0.05$ ) or did not affect $(400 \mathrm{MPa}$ sample, $P>0.05)$ the ORAC-FL values of the $22^{\circ} \mathrm{C}$ samples from 14.1 for the control cheese to 8.0 for $200 \mathrm{MPa}, 5 \mathrm{~min}$ sample and 14.0 for the $400 \mathrm{MPa}, 5 \mathrm{~min}$ sample. Pressure of $600 \mathrm{MPa}$ for $5 \mathrm{~min}-$ utes, however, significantly increased $(P<0.05)$ the ORAC-FL value of the $22^{\circ} \mathrm{C}$ cheese to 46.4 , indicating at some threshold pressure, the effect switches from diminishing to enhancing the antioxidative activity. This may be due to the fact that at high enough pressures (600 $\mathrm{MPa}$ ), extensive protein unfolding and breakdown has resulted in the formation of antioxidative peptides. This is supported by the fact that longer pressurization times (10 and $20 \mathrm{~min}$ ) at both 200 and $400 \mathrm{MPa}$ for the lower temperature cheeses leads to an increase in ORAC-FL value relative to the control sample, indicating that at lower pressures, more time may be needed for protein conformational change and/or bioactive peptide formation to occur. The value for the $22^{\circ} \mathrm{C}$ sample held at 200 $\mathrm{MPa}$ for $20 \mathrm{~min}$ was slightly higher $(P>0.05)$ than the sample held at $200 \mathrm{MPa}$ for $10 \mathrm{~min}$, indicating that this effect may be less pronounced after longer exposure times. This is also observed with the cheese held at 400 MPa for 20 min that was significantly less active $(P<$ 0.05 ) than the one held at the same pressure for $10 \mathrm{~min}$, indicating that prolonged exposure to $400 \mathrm{MPa}$ pressure had deleterious effects. In these cases, it is possible that any positive degradation effects that are achieved by exposure to high pressure are canceled out by solubility problems within the cheese or inactivation of any proteases contributing to bioactive peptide formation. This effect is even more pronounced in the $600 \mathrm{MPa}$ pressurized cheeses that show a substantial and significant drop off in activity with time.

Different trends are observed with the higher core temperature $\left(40^{\circ} \mathrm{C}\right)$ cheeses. At all three pressures, a significant decrease $(P<0.05)$ in ORAC-FL value relative to the control sample is observed after $5 \mathrm{~min}$. The $200 \mathrm{MPa}$ samples show a significant decrease $(P<0.05)$ from 5 to $10 \mathrm{~min}$ at $200 \mathrm{MPa}$ pressure and then a significant increase $(P<0.05)$ to control sample levels of activity after $20 \mathrm{~min}$ processing time. The activity levels of the 600 MPa samples initially decrease after 5 min under pressure and slightly increases after $10 \mathrm{~min}(P<0.05)$ but activity remains the same from 10 to 20 min under pressure. The $400 \mathrm{MPa}$ samples show a significant increase $(P<0.05)$ in activity with longer durations under pres- 
sure, with the levels of the cheese processed for $20 \mathrm{~min}$ at $400 \mathrm{MPa}$ one and a half times that of the control sample. These conditions may have been optimal for proteolytic activity that resulted in a far greater concentration of antioxidants. It may also be that antioxidative peptides have been generated that are appreciably more active, resulting in much higher ORAC-FL levels overall.

\section{CONCLUSIONS}

The results presented here show that the antioxidative activities of proteins from dairy products like QFs can be measured and that temperature and pressure are important processing parameters that affect these activities in QFs and potentially other dairy products. To fully understand the impact that these HPP variables have on overall antioxidative activity of milk products, an extensive identification and characterization of the active components in the protein extract mixtures must be carried out. Future experiments will focus on determining the actual active antioxidants in the mixtures studied here as well as in other cheeses. The antioxidant capacities of a number of common foods have been measured and reported previously [36]. While the ORAC-FL values of foods known to be potent antioxidants (e.g. 175.24 TE/g for pecans and 399.31 TE/g for turmeric) are generally higher than those measured for cheese proteins in this study, the highest ORAC-FL value measured here for the $40^{\circ} \mathrm{C}$ cheese sample processed at $400 \mathrm{MPa}$ for $20 \mathrm{~min}$ (89.8 TE/g) is comparable to some known active foods like cranberries $(92.56 \mathrm{TE} / \mathrm{g})$ and hazelnuts $(92.75 \mathrm{TE} / \mathrm{g})$. Therefore, achieving the maximum potential antioxidative activity in cheese through increasing the overall concentration and bioavailability of the active components in milk may lead to cheese and other dairy products with increased nutritional benefits. It is important to note that while the $40^{\circ} \mathrm{C}$ cheeses in this study are generally more antioxidatively active than the lower temperature ones, rheological studies of these cheeses have shown the increased temperature impacts a number of functional qualities of the cheeses, e.g. increased wheying off, higher values for hardness, chewiness, cohesiveness, shear stress and shear strain (D. Van Hekken, unpublished work). Regardless, further work will determine if HPP is in fact promoting and/or inhibiting formation of these active components or if there are other governing factors influencing the bioactivity of these and other dairy products.

\section{ACKNOWLEDGEMENTS}

The authors would like to acknowledge the following USDA-ARSNAA-ERRC researchers: Dr. Peter Irwin for use of the fluorometer, Mr. Raymond Kwoczak, Ms. Latasha Leggett, Mr. John Minutolo for tech- nical assistance, and Dr. John Phillips for statistical analysis.

\section{REFERENCES}

[1] Hasler, C.M. (2002) Functional foods: Benefit, concerns and challenges-A position paper from the American Council on Science and Health. The Journal of Nutrition, 132, 3772-3781.

[2] Gad, A.S., Khadrawy, Y.A., El-Nekeety, A.A., Mohamed, S.R., Hassan, N.S. and Abdel-Wahhab, M.A. (2011) Antioxidant activity and hepatoprotective effects of whey protein and Spirulina in rats. Nutrition, 27, 582-589. doi:10.1016/j.nut.2010.04.002

[3] Andre, C.M., Larondelle, Y. and Evers, D. (2010) Dietary antioxidants and oxidative stress from a human and plant perspective: A review. Current Nutrition and Food Science, 6, 2-12. doi:10.2174/157340110790909563

[4] Davalos, A., Miguel, M., Bartolome, B. and Lopez-Fandino, R. (2004) Antioxidant activity of peptides derived from egg white proteins by enzymatic hydrolysis. Journal of Food Protection, 67, 1939-1944.

[5] Lim, K., Ma, M. and Dolan, K.D. (2011) Effects of spray drying on antioxidant capacity and anthocyanidin content of blueberry by-products. Journal of Food Science, 76, H156-H164. doi:10.1111/j.1750-3841.2011.02286.X

[6] Hudthagosol, C., Haddad, E.H., McCarthy, K., Wang, P., Oda, K. and Sabate, J. (2011) Pecans acutely increase plasma postprandial antioxidant capacity and catechins and decrease LDL oxidation in humans. Journal of Nutrition, 141, 56-62. doi:10.3945/jn.110.121269

[7] McKay, D.L., Chen, C.Y., Yeum, K.J., Matthan, N.R., Lichtenstein, A.H. and Blumberg, J.B. (2010) Chronic and acute effects of walnuts on antioxidant capacity and nutritional status in humans: A randomized, cross-over pilot study. Nutrition Journal, 9, 21. doi:10.1186/1475-2891-9-21

[8] Heber, D. and Bowerman, S. (2001) Applying science to changing dietary patterns. Journal of Nutrition, 131, 3078S$3081 \mathrm{~S}$.

[9] Saiga, A., Tanabe, S. and Nishimura, T. (2003) Antioxidant activity of peptides obtained from porcine myofibrillar proteins by protease treatment. Journal of Agricultural and Food Chemistry, 51, 3661-3667. doi:10.1186/1475-2891-9-21

[10] Shahidi, F. and Amarowicz, R. (1996) Antioxidant activity of protein hydrolyzates from aquatic species. Journal of the American Oil Chemists' Society, 73, 1197-1199.

[11] Korhonen, H. (2009) Milk-derived bioactive peptides: From science to applications. Journal of Functional Foods, 1, 177-187. doi:10.1016/j.jff.2009.01.007

[12] Hernandez-Ledesma, B., Davalos, A., Bartolome, B. and Amigo, L. (2005) Preparation of antioxidant enzymatic hydrolysates from $\alpha$-lactalbumin and $\beta$-lactoglobulin. Identification of active peptides by HPLC-MS/MS. Journal of Agricultural and Food Chemistry, 53, 588-593. doi:10.1021/jf048626m

[13] Salami, M., Moosavi-Movahedi, A.A., Ehsani, M.R., Yousefi, R., Haertle, T., Chobert, J.M., Razavi, S.H., Henrich, 
R., Balalaie, S., Ebadi, S.A., Pourtakdoost, S. and NiasariNaslaji A. (2010) Improvement of the antimicrobial and antioxidant activities of camel and bovine whey proteins by limited proteolysis. Journal of Agricultural and Food Chemistry, 58, 3297-3302. doi:10.1021/jf9033283

[14] Sreeramulu, D. and Raghunath, M. (2011) Antioxidant and phenolic content of nuts, oil seeds, milk and milk products commonly consumed in India. Food and Nutrition Sciences, 2, 422-427. doi:10.4236/fns.2011.25059

[15] Paul, M. and Van Hekken, D.L. (2011) Short communication: Assessing antihypertensive activity in native and model Queso Fresco cheeses. Journal of Dairy Science, 94, 2280-2284. doi:10.3168/jds.2010-3852

[16] Torres-Llanez, M.J., Gonzalez-Cordova, A.F., HernandezMendoza, A., Garcia, H.S. and Vallejo-Cordoba, B. (2011) Angiotensin-converting enzyme inhibitory activity in Mexican Fresco cheese. Journal of Dairy Science, 94, 37943800. doi:10.3168/jds.2011-4237

[17] Guo, L., Van Hekken, D.L., Tomasula, P.M., Shieh, J. and Tunick, M.H. (2011) Effect of salt on the chemical, functional, and rheological properties of Queso Fresco during storage. International Dairy Journal, 21, 352-357. doi:10.1016/j.idairyj.2010.12.009

[18] Tunick, M.H., Malin, E.L., Smith, P.W. and Holsinger, V.H. (1995) Effects of skim milk homogenization on proteolysis and rheology of Mozzarella cheese. International Dairy Journal, 5, 483-491. doi:10.1016/0958-6946(95)00026-Y

[19] Ou, B., Hampsch-Woodill, M. and Prior, R.L. (2001) Development and validation of an improved oxygen radical absorbance capacity assay using fluorescein as the fluorescent probe. Journal of Agricultural and Food Chemistry, 49, 4619-4626. doi:10.1021/jf010586o

[20] Davalos, A., Gomez-Cordoves, C. and Bartolome, B. (2004) Extending applicability of the oxygen radical absorbance capacity (ORAC-Fluorescein) assay. Journal of Agricultural and Food Chemistry, 52, 48-54. doi:10.1021/jf0305231

[21] SAS Institute (1999) SAS/STAT user's guide. Version 8, SAS Institute Inc., Cary.

[22] Blando, F., Gerardi, C. and Nicoletti, I. (2004) Sour cherry (Prunus cerasus L.) anthocyanins as ingredients for functional foods. Journal of Biomedicine and Biotechnology, 2004, 253-258. doi:10.1155/S1110724304404136

[23] Bolling, B.W., Blumberg, J.B. and Chen, C.Y. (2009) Extraction methods determine the antioxidant capacity and induction of quinone reductase by soy products in vitro. Food Chemistry, 116, 351-355. doi:10.1016/j.foodchem.2009.01.087

[24] Crozier, S.J., Preston, A.G., Hurst, J.W., Payne, M.J., Mann, J., Hainly, L. and Miller, D.L. (2011) Cacao seeds are a "Super Fruit": A comparative analysis of various fruit powders and products. Chemistry Central Journal, 5, 5. doi:10.1186/1752-153X-5-5

[25] Tijerina-Saenz, A., Innis, S.M. and Kitts, D.D. (2009) Antioxidant capacity of human milk and its association with vitamins A and E and fatty acid composition. Acta Paediatrica, 98, 1793-1798.

doi:10.1111/j.1651-2227.2009.01437.x

[26] Chen, J., Lindmark-Mansson, H., Gorton, L. and Akesson, B. (2003) Antioxidant capacity of bovine milk as assayed by spectrophotometric and amperometric methods. International Dairy Journal, 13, 927-935. doi:10.1016/S0958-6946(03)00139-0

[27] Clausen, M.R., Skibsted, L.H. and Stagsted, J. (2009) Characterization of major radical scavenger species in bovine milk through size exclusion chromatography and functional assays. Journal of Agricultural and Food Chemistry, 57, 2912-2919. doi:10.1021/jf803449t

[28] Ostdal, H., Andersen, H.J. and Nielsen, J.H. (2000) Antioxidative activity of urate in bovine milk. Journal of Agricultural and Food Chemistry, 48, 5588-5592. doi:10.1021/jf000658w

[29] Huppertz, T., Fox, P.F. and Kelly, A.L. (2004) High pressure treatment of bovine milk: Effects on casein micelles and whey proteins. Journal of Dairy Research, 71, 97106. doi:10.1017/S002202990300640X

[30] Needs, E.C., Stenning, R.A., Gill, A.L., Ferragut, V. and Rich, G.T. (2000) High-pressure treatment of milk: Effects on casein micelle structure and on enzymic coagulation. Journal of Dairy Research, 67, 31-42. doi:10.1017/S0022029999004021

[31] Huppertz, T., Fox, P.F., de Kruif, K.G. and Kelly, A.L. (2006) High pressure-induced changes in bovine milk proteins: A review. Biochimica et Biophysica Acta, 1764, 593-598. doi:10.1016/j.bbapap.2005.11.010

[32] Ismail, B. and Nielsen, S.S. (2010) Invited review: Plasmin protease in milk: Current knowledge and relevance to dairy industry. Journal of Dairy Science, 93, 4999-5009. doi:10.3168/jds.2010-3122

[33] Hurley, M., Larsen, L.B Kelly, A.L. and McSweeney, P.L.H. (2000) The milk acid proteinase cathepsin D: A review. International Dairy Journal, 10, 673-681. doi:10.1016/S0958-6946(00)00100-X

[34] Moatsou, G., Bakopanos, C., Katharios, D., Katsaros, G., Kandarakis, I., Taoukis, P. and Politis, I. (2008) Effect of high-pressure treatment at various temperatures on indigenous proteolytic enzymes and whey protein denaturation in bovine milk. Journal of Dairy Research, 75, 262-269. doi:10.1017/S002202990800321X

[35] Belloque, J., Chicon, R. and Lopez-Fandino, R. (2007) Unfolding and refolding of $\beta$-lactoglobulin subjected to high hydrostatic pressure at different $\mathrm{pH}$ values and temperatures and its influence on proteolysis. Journal of Agricultural and Food Chemistry, 55, 5282-5288. doi:10.1021/jf070170w

[36] Wu, X., Beecher, G.R., Holden, J.M., Haytowitz, D.B., Gebhardt, S.E. and Prior, R.L. (2004) Lipophilic and Hydrophilic antioxidant capacities of common foods in the United States. Journal of Agricultural and Food Chemistry, 52, 4026-4037. doi:10.1021/jf049696w 